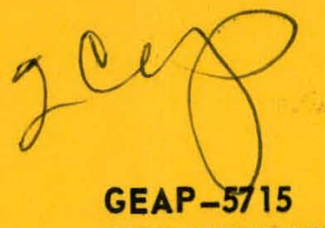

AEC RESEARCH AND DEVELOPMENT REPORT

DECEMBER 1968

\title{
FINAL FAST FLUX TEST FACILITY BACKUP DESIGN DEVELOPMENT REQUIREMENT REPORT
}

COMPILED BY

P.R. PLUTA

U.S. ATOMIC ENERGY COMMISSION CONTRACT NUMBER BDR-341

BETWEEN PACIFIC NORTHWEST LABORATORY AND THE GENERAL ELECTRIC COMPANY
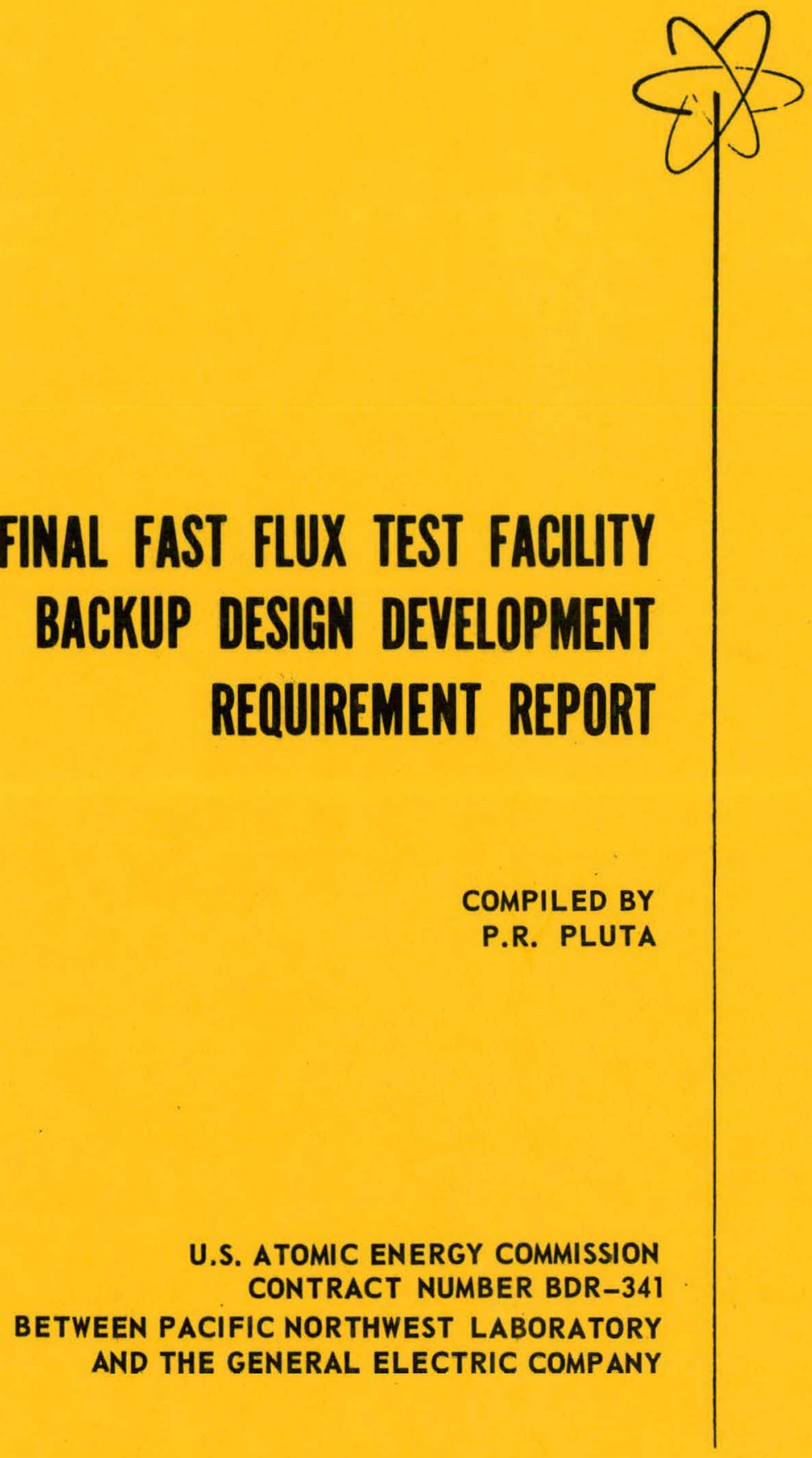


\section{DISCLAIMER}

This report was prepared as an account of work sponsored by an agency of the United States Government. Neither the United States Government nor any agency Thereof, nor any of their employees, makes any warranty, express or implied, or assumes any legal liability or responsibility for the accuracy, completeness, or usefulness of any information, apparatus, product, or process disclosed, or represents that its use would not infringe privately owned rights. Reference herein to any specific commercial product, process, or service by trade name, trademark, manufacturer, or otherwise does not necessarily constitute or imply its endorsement, recommendation, or favoring by the United States Government or any agency thereof. The views and opinions of authors expressed herein do not necessarily state or reflect those of the United States Government or any agency thereof. 


\section{DISCLAIMER}

Portions of this document may be illegible in electronic image products. Images are produced from the best available original document. 


\section{FINAL FAST FLUX TEST FACILITY BACKUP DESIGN \\ DEVELOPMENT REQUIREMENT REPORT}

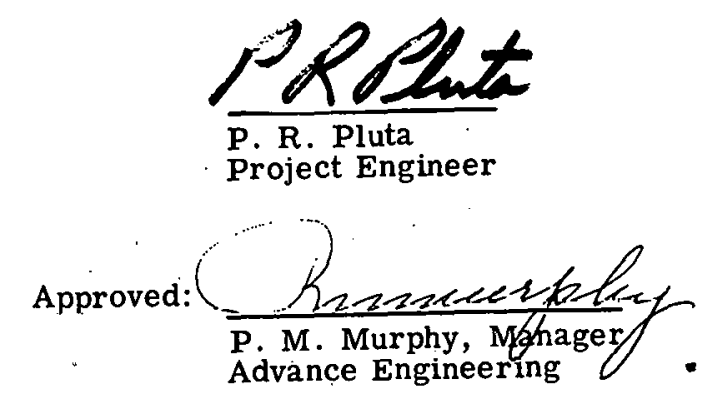

Prepared for the

U. S. Atomic Energy Commission

Under Contract Number BDR-341

Between Pacific Northwest Laboratory

and the General Electric Company

Printed in U.S.A. Available from the

Clearing House for Federal Scientific and Tecbnical Information

National Bureau of Standards, U.S. Bepartmenti of Commerce

Spring/ield, Virginia

Price: $\$ 3.00$ per copy sponsored by the United States Government. Neither the United States nor the United States Atomic Energy Commission, nor any of thei eiriployees, nor any of their contractors, subcontractors, or their employees, makes any warranty, express or implied, or assumes any legal liability or responsibility for the accuracy, completeness or usefulness of any information, apparatus, product or process disclosed, or represents that its use would not infringe privately owned rights.

\section{GENERAL GLECTRIC \\ SUMNYVALE, CALIFORNIA}




\section{LEGAL NOTICE}

This report was prepared as an account of Government sponsored work. Neitber the United States, nor the Commission, nor any person acting on bebalf of the Commission:

A. Makes any warranty or representation, expressed or implied, with respect to the accuracy, completeness, or usefulness of the information contained in this report, or that the use of any information, apparatus, method, or process disclosed in this report may not infringe privatcly owned rights; or

$B$. Assumes any liabilities with respect to the use of, or for damages resulting from the use of any information, apparatus, method, or process disclosed in this report.

As used in the above, "person acting on behalf of the Commission" includes any employee or contractor of the Commission, or employee of such contractor, to the extent that such employee or contractor of the Commission, or employee of sucb contractor prepares, disseminates, or provides access to, any information pursuant to his employment or contract with the Commission, or bis employment with such contractor. 


\section{TABLE OF CONTENTS}

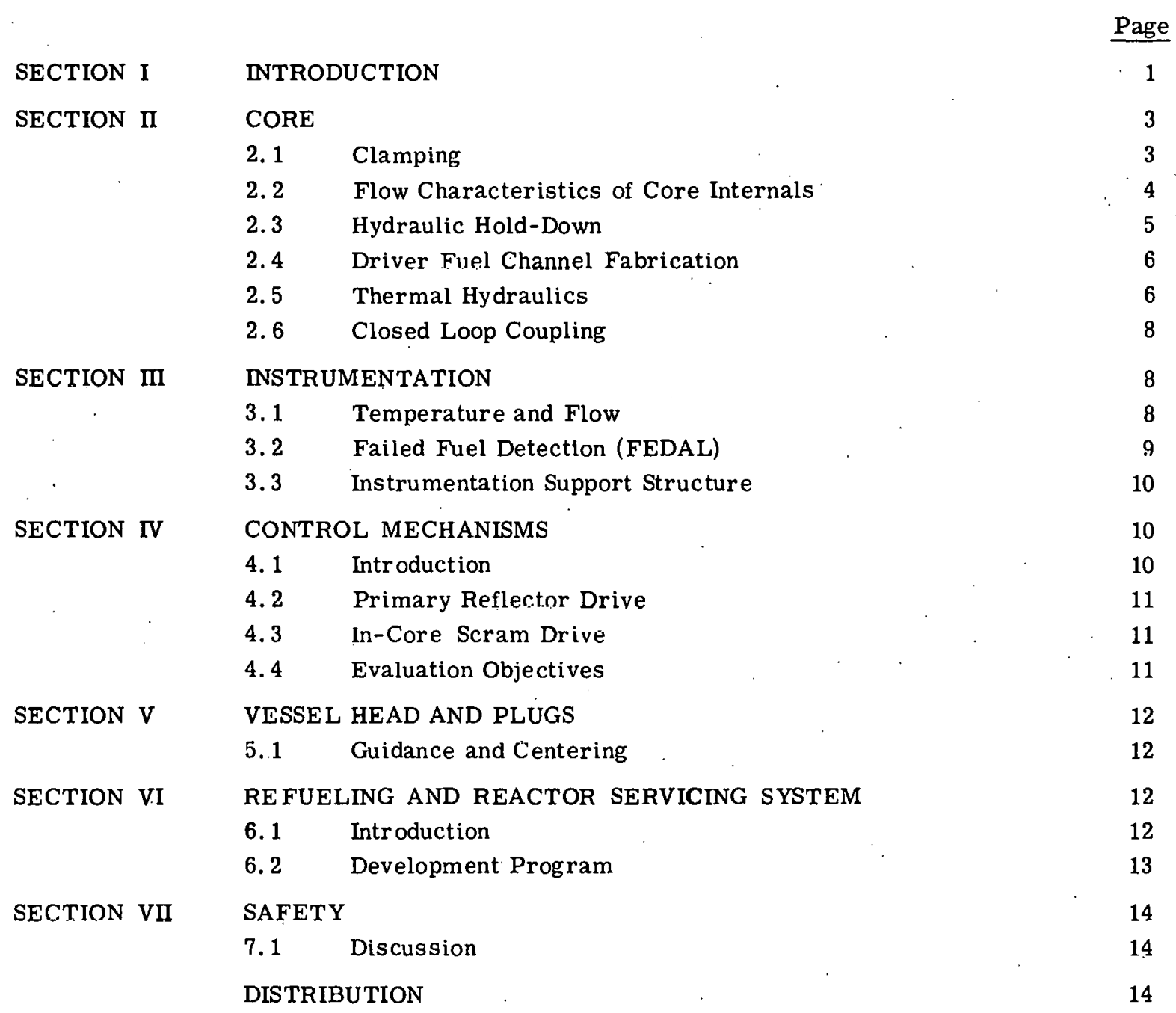




\section{INTRODUCTION}

The objective of the FFTF backup design was to provide the capability for replacing the reference FFTF dispersed core design at any point in its evolution, with an open lattice vertical core and associated handling system, instrumentation, control rod, and head configuration making use of the reference design vcssel, hot cell, coolant system, atc. Contract BDR-341 and its attached Statement of Work between Facific Northwest Laboratories (PNL) and the General Electric Company authorized that the backup design be developed with sufficient design details and design spec ifications to establish its feasibility when coupled with the required engineering development program. Layout drawings were to be completed in sufficient design detail to obtain cost cstimates, establish feasibility, and to allow the development of shop fabrication drawings from the basic information contained.

The General Electric Company was advised by Pacific Northwest Laboratories in October 1868 that a new reference FFTF concept had been selected. PNL requested that all design activity un llie $\mathrm{GE}$ backup design be terminated and the cornpleted work be summarized in a Final De sign Report. In addition, PNL requested that a document describing the development programs to support the backup design concept be prepared. This report, GE $\Lambda \mathrm{P}-5715$, describes the supporting development programs. Reports which descrilue dud complement the backup design are:

- Topical Reports

GEAP-4470 An Engineering Review of the Fast Flux Test Facility - Phase I, .T. H. Field, May 1966.
Topical Reports

GEAP-5290

Fast Flux Test Facility Functional Requirements, C. N. Spalaris, October 1966.

GEAP-5422 Fast Flux Test Facility Phase II Study -A Conceptual Design of the Fast Flux Test Facility Reactor System, W. J. Clabaugh, December 1966.

GEAP-5551

The Selection of a Pipe Loup System for the Fast Flux Tesl Facility, W.W. Kendall and G. B. Kruger, October 1967

GEAP-5552 Conceptual Design of the Backup Reactor System for the Fast Flux Test Facility, D. R. Riley, August 1967.

FFA A -5660 Sodium Temperature Response to Transients in the Fast Flux Test

Facility Conceptual Backup Design and Description of Dynamics Model, $\Lambda$. B. Reynolds and P. C. Vaughan, September 1968 .

GEAP-5721 Fast Flux Test Facility Backup Design Interface Definition Discussion of System Requirements, G. Kruger, W. Kendall, and D. Mitome, December 1968. 
GEAP-5722 Final Fast Flux Test Facility Backup Design Summary Report, P. R. Pluta, January 1969.

- Quarterly Reports

GEAP-5550 Fast Flux Test Facility Backup Design Project First Quarterly Report, May-August 1967, October 1967.

GEAP-5614 Fast Flux Test Facility Backup Design Project Second Quarterly Re port, September November 1967, April 1968.

GEAP-5641 Fast Flux Test Facility Backup Design Project Third Quarterly Report, December-February 1968, July 1968.

GEA P-5650 Fast Flux Test Facility Backup Design Project Fourth Quarterly Re port, March-May 1968, July 1968.

GEA P-5684 Fast Flux Test Facility Backup Design Project Fifth Quarterly Report, June-August 1968, November 1968.

These reports should be thoroughly studied bcfore reading the development programs in support of the backup design. It will be assumed throughout this report that the reader is familiar with all aspects of the backup design.

It is presumed that the reader understands the engineering problems associated with the backup design and can relate this understanding to the present state-of-theart regarding sodium reactor component development.

The status of the backup design effort, as described in the Final Design Summary Report GEAP-5722, is incomplete because of the decision to terminate the backup design activity.

This development program is directed at FFT F features that are unique to the backup design. This means that development programs which would be necessary for the reference FF.TF design (in areas such as fuel pin irradiation testing, materials evaluation, etc.) generally will not be repeated in this report. Development tasks for the backup design generally will not be discussed in this report where only minor modifications or extensions of development programs are already in place or are known to be required for the prior reference FFTF design. Comments received from PNL on an earlier GE draft of the required development program were very helpful in pointing out those areas where there was no need for delialled description because of programs planned for the reference FFTF concept. 


\section{SECTION II}

\subsection{CLAMPING}

A structure surrounds the core and reflector radially. The core clamping mechanisms, based on the SEFOR tor sion bar concept, act against this structure to prevent gross core movement during all operational phases of the FFTF except refueling. Confirmation or modification of the hardware design bases of the FFTF backup design related to core clamping and the associated hex channel load transfer, manufacturing tolerance buildups, temperature gradient bowing effects, mating parl operation in sodium, and cyclic operation of the clamping devices should be accomplished. The effectiveness of the core hardware should be determined in accomplishing its design function of minimizing core motions that would contribute to significant reactivity swings.

Simulate the internals and clamping mechanisms with a reduced scale mockup (not less than $1 / 2$ scale) incorporating where practical, tolerance variations and distortions anticipated in the design to evaluate the load transfer characteristics and tolerance and distortion impact on load transfer characteristics of the internals clamping system.

Simulate the reactor internals and clamping mechanism over a partial arc. of the internals $\left(30^{\circ}\right.$ to $60^{\circ}$ segment) in a full scale heated model in air and, if practical, sodium environments, to determine the effects of bowing and tolerances on clamping operations, the loading introduced under extreme of tolerance and bowing, the opera- tional characteristics of the system, and the recommended operational procedures of the clamping system. The most important feature of the model is to establish the temperature gradient across the channels.

Simulate the loading cycles on full scale models of the individual clamping devices in sodium to determine their life and fatigue cycle characteristics under design operating environment and loading conditions.

The test configuration should have the capability to simulate the various operational modes and flow regimes of the reactor and to be instrumented as required.

Infor mation required on core clamping follows:

- Determine the clamping characteristics of the system under operating conditions.

- Determine acceptable tolerance range on internals hexagonal dimensions.

- Establish clamping and unclamping operational procedures compatible with cla mping functions and operational limitations.

- Assess the effect of channel bowing and resultant loading patterns and load levels.

- Establish minimım clamping requirements.

- Determine clamping device and endurance characteristice. 


\subsection{FLOW CHARACTERISTICS OF CORE INTERNALS}

Experimental confirmation or modification of analytical predictions of the reactor flow characteristics under various operating conditions should be accomplished in the areas of mixing of core outlet coolant flow in the upper plenum, flow distribution in the lower plenum and the inlet nozzles, gas entrainment and surface turbulence at free sodium surface in the vessel, core channel exit losses, and flow induced vibration of structural or instrument components in the plenum above the core.

Simulate the reactor internals flow and structural characteristics for the environmental and operational range required of the system. A half-scale water model should be built for test simulating the reactor internals flow areas including the inlet and outlet plenum areas, reactor core (including the radial or ificing characteristics) areas, adjacent to the core, outlet structural and instrumentation configuration.

\subsubsection{Information Required on Core} Flow Characteristics

- Budium flow stratification and/or mixing characteristics of outlet plenum under various operational conditions.

- Flow distribution in inlet plenum.

- Effect of tolerance, wear and alignment un the seal in the hydraulic holddown system.

- Flow distribution in reactor (i.e., core, control rods, reflector, shielding).

- Determine outlet plenum surface turbulence characteristics.
- Determine outlet plenum gas entrainment characteristics.

- Evaluate necessity of and form of equipment and/or procedures required to minimize outlet plenum surface turbulence and gas entrainment.

- Determine core channel exit pressure lósses.

- Determine vibrational characteristics of structural and instrumentation components in outlet plenum area.

\subsubsection{Example of Core Hydraulic Testing (Water) Specific Tests}

The primary purposes of this series of half scale water tests are as follows:

- Measure pressure distribution in lower plenum including all inlet nozzles supplying flow (part load through rated).

- Measure pressure distribution in lower plenum with one inlet nozzle not supplying flow (part load through rated).

- Determine the degree of mixing between core outlet flow and the upper plenum pool over the range of conditions. Determine the temperature transient at the sodium surface as a function of expected transient conditions.

- Fivaluate the gas entrainment potential due to surface turbulence.

- Determine core channel exit losses.

- Identify any potential problems associated with flow induced vibration in the instrumentation support structure above the core outlet. 
The half scale model includes the lower and upper plenum regions and simulates the fuel bundle by means of reduced length tubes containing an adjustable orifice to achieve the pressure drop of the subassembly internals. A $360^{\circ}$ model is required in order to evalu ate non-symmetric flow effects when operation with one loop down is simulated.

During the detail test planning and design phase, the practicability of incorporating both plenums into the same model and retaining the flexibility for making design modifications and incorporating instrumentation can be determined; a decision to build one composite model or two separate models can be made.

A pressure map of the lower plenum coupled with the pressure drop calibration, the measurements on a single channel described in subsection 2.5, and measurements of exit losses will provide the basis for sizing the inlet orifices in the design and evaluating the tolerance to be incorporated into channel flow and temperature predictions. Static pressure and velocity probes can be incorporated in the plenum and on each side of restricted sections of the simulated channel. The pressure map can also be determined for non-symmetric flow from inlet nozzles. The flexibility to allow change and to modify baffles in the lower plenum and the diameter and depth of the plenum should be incorporated in the design of the model.

The capability of the baffles and structure in the upper pool to moderate the rate of cliange in core outlct temperature on the vessel outlet nozzle by mixing should be determined in order to evaluate the temperature gradients seen by the outlet nozzle during flow transients. Relating the response of thermocouples at the core outlet to thermocouples at the outlet nozzle when the inlet temperature is rapidly reduced should permit an approximate estimate of the transient effect.

Gas entrainment tests can be run by varying the height from the top of the core bundle to the free surface. Fluid properties can be partially simulated by proper selection of the water temperature. Visual observation of the pool surface can be made to qualitatively assess gas entrainment due to fountain, vortex, and surface turbulence effects. Performing tests at various surface levels may show a relationship between vortex formation and pool depth. Geometry modifications to ameliorate such problems if they occur can be investigated.

Channel exit losses can be measured by pressure probes at various radial locations in the burdle both inside and above the channel exit.

Accelerometcrs, strain gages, or both, will be installed in components (such as cantilevered instrumentation probes) suspected as subject to potential vibration and the vibration measured.

\subsection{HYDRAULIC HOLD-DOWN}

The effects of tolerances, wear, distortions of the hydraulic hold-down structure as well as of the hydraulic hold-down section of the fuel channel assembly on the leakage and operational characteristics of the hydraulic hold-down design must be evaluated experimentally with sodium so that the results may be factored into the design details.

\subsubsection{Information Required on Hydraulic Hold-Down}

- Determine the by-pass flow characteristics and hold-down loading as a funcliun of $\Delta \mathrm{p}$, tolerance, and disdistortions. 
- Determine the life-cycle wear and distortion characteristics under the environmental conditions over the design range of loading, tolerance, and distortion characteristics as well as under simulated handling operations loads.

- Evaluate loading characteristics resulting from fuel chamel assembly clamping, misalignment between upper and lower grid plate holes, distortion, and handling operations.

\subsection{DRIVER FUEL CHANNEL FABRICATION}

Establish realistic fuel channel and fuel channel assembly fabrication procedures for the FFTF Backup Design fuel channel and fuel channel assembly to assure design fabricability. Fabricate several channels to meet subassembly tolerance and specification requirements. Fabricate sev eral dummy fuel channel assemblies to meet assembly tolerance and specification rerequirements.

\subsubsection{Information Required for Incoloy and Steel Fabrication}

Specify:

- Fabrication process

- Inspection procedures

- Process results

- Recommended dimensional tolerances

- Allowance for swelling and distortions

- Critical area evaluations

- Transition sections

- Weld sections

- Attachment points

- Residual stresses

- Tooling requirements

- Materlal procurement specifications

- Quality control

- Cleaning

- Storage

\subsection{THERMAL HYDRAULICS}

It is necessary because of the uncertainty in driver fuel assembly thermal-hydraulics analysis methods to confirm the thermal-hydraulic design basis of the driver fuel assembly. The pressure drop across the fuel section and channel assembly, local velocity distributions in the driver fuel as well as in the channel assembly inlet and outlet sections, driver fuel section temperature characteristics, and the fuel pin assembly vibration characteristics must be evaluated experimentally and compared with analytical analyses so design confirmation or design modification may be accomplished.

The required engineering tests are summarized below:

- Water tests on full scale model of the fuel pin region to determine the pressure drop and vibration characteristics of the fuel pin assembly, including the nose piece and shielding sections.

- Large scale water tests of local flow distribution to determine the local flow velocity distribution around individual pins and spacers.

- Full scale mockup of the channel assembly in liquid sodium to determine the hydraulic behavior of the design under operating conditions, including orifice characterization.

\subsubsection{Required Information from Test Program}

- Channel assembly axial pressure drop characteristics

- Frequency and amplitude of flow induced vibration

- Fretting and wear characteristics of assembly 
- Inlet and outlet flow velocity distribution

- Local axial and cross flow velocities

- Effects of manufacturing tolerances on thermal-hydraulic characteristics

- Local fuel pin assembly temperature characteristics.

\subsubsection{Examples of Specific Thermal- Hydraulic Test Programs}

\subsubsection{Water Tests of Full Scale Model of the Fuel Pin Region}

The objectives of this test series are to determine the pressure drop and flow induced vibrational behavior of the fuel pin region of the fuel subassembly. The pins should be modeled using lead or other heavy filler so that the ratio of mass per unit length to axial bending stiffness at operating conditions are simulated. The following types of design features will require experimentation to establish pressure drop and vibration characteristics.

a. Wire Wrap. The pitch of spiral wire wrap spacers should be ás large as foasible from pressure drop considerations. The bounds on this are set by vibration and fuel pin bowing. The upper limit from vibration considerations could be established by tests in this series. The bundles tested should be made up to reflect the maximum degree of looseness anticipated under operating conditions at a. wire wrap pitch value necessary to control bowing due to non-uniform temperatures. Should vibration problems attributed to axial distance between supports occur, testing at a further reduction in pitch will be necessary. Potential vibration attributed to general looseness will require alternate design methods of removing this.

b. Edge Geometry. In a uniform array of pins in a hexagonal channel, the pins in the outer row are overcooled relative to the interior pins of the array; a means for minimizing this overcooling is desirable. Various design ideas are conceptually promising. Experimental evaluations of different design approaches to minimize this effect are required.

c. Alternate Spacer Designs Since there are alternate promising spacer design approaches, it is recommended that testing of at least one alternate be planned as a backup or improve ment to the reference wire wrap scheme.

\subsubsection{Water Tests on Fuel Subassembly Inlet Region}

The purpose of this series of tests would be to calibrate the inlet orifice and to determine hold down force on channel and bypass flows as a function of design and tolerance clearances. The mockup should simulate the geometry of the upper and lower grid plates. The fuel region pressure drop can be simulated by a simple adjustable orifice. Clearance at the seat and lower grid plate should be variable by using inserts, shims, etc.

The flow through the simulated fuel orifice should be measured over the design pressure range for various degrees of throttling of the inlet orifice. These calibration curves will be used to establish the orifice size for the several radial regions 
of the core. The downstream resistance of the bypass flows are relatively small and can be simulated by adjustable orifices also.

\subsubsection{Large Scale Water Tests of Local Flow Distribution}

Since it is very difficult to measure local flow in a full scale test, a $6 \mathrm{x}$ scale test is recommended to study the local velocity distribution around individual pins. Such information can be factored into the analysis for prediction of temperature variation around the circumference of the individual fuel pins and effects of geometry variations on local cooling. By using such a scale, velocity probes can be inserted and the flow perturbation associated with the probe minimized by using the smallest diameter feasible ( $\sim 0.030$ inches in diameter). The velocity map around typical interior and typical exterior pins would be obtained. The model should mock up typical external and interior pins. A one-third sector, 5 row array, should be sufficient for the purposes of this test. The wire or other spacing devices should be removable and interchangeable to provide flexibility in selection of test geometries. The effects of deviations from nominal flow areas due to tolerances, materiel swelling, and possible distortions (including the offects of displaced, tilted and bowed rods) should be evaluated. Spacers can be removed for such testing. The effect of alternate edge pin coolant area geometries will be investigated to support design selection decisions.

\subsection{CLOSED LOOP COUPLING}

The closed loops are designed to be removed and replaced through the small refueling opening in the main head. To accomplish this the pipe flanges must be uncoupled and reconnected through this refueling opening. It is intended that mechanical couplings be used for this purpose. Since a wide variety of coolants is expected, the integrity of the coupling is extremely important and it will be assumed that there can be no leakage. The location of the coupling requires that it be operated by remote means.

The development program will include the design and fabrication of several prototype couplings and support to be used for test purposes. The test should demonstrate that the coupling can be repeatedly made and broken by remote means and remain leak tight. The prototype coupling should be examined during the test program to determine if there are areas that require further design work.

The assembly and disassembly part of the test program requires no special envi:ronment. The important part of this test is to demonstrate that the coupling can be assembled with tools designed for that purpose. The coupling must be leak and life tested under environmental conditions simulating those found in the reactor.

\section{SECTION III}

\section{INSTRIJMENTATION}

\subsection{TEMPERATURE AND FLOW}

A compact sensor module that is inserted into the outlet of each driver fuel bundle and is supported by the instrument harness attached to the head refueling plug is required. The sensor module is pre- sently conceived as ronta ining both temperature and flow instrumentation. Three active thermocouples using two out of three logic and one spare thermocouple are contained in the module. The thermocuuples must exhibit good accuracy. The flow measurement can be accomplished in a number 
of ways as described in GEAP-5722. The flow indication is primarily intended as a backup to the thermocouples to detect major flow blockage in a subassembly. As a result, accuracy can be relatively low.

Since the driver fuel thermocouple instrumentation system is to be tied to the reactor scram circuit, the ability of the system to operate in the reactor environment, to be easily repaired and have a low failure rate has a direct impact in reactor plant availability. In order to have a high degree of assurance of acceptable operation of the thermocouple system prior to operaling the reactor, the system design must be exercised under design environmental and simulated cycle and life conditions.

It is desirable to test fuel channel thermocouple instrumentation packages (4 thermocouples per package) and corresponding majority logic electronic circuitry under the temperature, transient, cycle, life, and handling environment to be encountered in the reactor plant operations.

Operational, maintenance, and handling characteristics of driver fuel flow instrumentation ohould be determined in order to confirm that the flow instrumentation developed can meet the required reactor system design characteristics: Sufficient information should be obtained to guide any redesigns that might be required in the event the design does not meet these requirements. It is desirable to test driver fuel channel flow instrumentation packages in sodium under the flow, tem:perature, transient, cycle, life and handling environment of reactor plant operations.

\subsubsection{Information Required for Instrument Tests}

\subsubsection{Thermocouple Aspects}

- Determine failure rate characteristics of the system as related to life, cycles, temperatures, rates of change of temperature, and handling operations.

- Determine the response characteristics of the system.

- Evaluate the maintenance characteristics of the system.

- Establish operational, handling and maintenance procedures for driver fuel thermocouple instrumentation as required to maximize plant availability.

\subsubsection{Flow Aspects}

- Determine failure rate characteristics of the system as related to life, cycle, temperature, rates of temperature change and handling.

- Evaluate the maintenance characteristics of the equipment.

- Establish operational, handling, and maintenance procedures for driver fuel flow instrumentation to minimize plant unavailability.

\subsection{FAILED FUEL DETECTION (FEDAL)}

The FFTF has a requirement that fuel failure be promptly detected and located within the core. The backup design concept is based on continuously sampling 
sodium at the outlet of each driver fuel subassembly and monitoring for delayed neutrons outside of the vessel. There are other means of detecting, but not necessarily locating, fuel failure, such as sampling for fission gas release. It will be necessary to confirm the design basis of the backup concept by testing a mockup of the sodium sampling line. The areas of special interest are:

- the sodium velocity past the sampling line entrance in order for the sodium to reach the head and transit the gap between the refueling plug and the annular plug

- the transit characteristics across the plug gaps

- the degree of fission product gas de-entrainment in the lines and gas loss through gaps

- the balance between the sodium being pumped from the line and the rate of sodium sampling under non-steady state conditions
- the effect of different driver fuei subassembly flow rates

- $\quad$ sensitivity and signal-to-noise ratio in a reactor

\subsection{INSTRUMENTATION SUP PORT. STRUCTURE}

The driver fuel instrumentation above the open lattice vertical backup core is supported by a harness attached to the refueling plug. The adequacy of the harness and support design with respect to flow induced vibration should be modeled. Water tests will be adequate to demonstrate the practicality of the detail design.

Check dimensional stability in the presence of expected temperature conditions, including the radial temperature gradient. Test and evaluate the system used to guide the structure and locate the instrument packages in the outlet of the fuel subassemblies.

\section{SECTION IV}

\section{CONTROL MECHANISMS}

\subsection{INTRODUCTION}

The purpose of the drive R\&D program is to develop two types of drives of different operational principles which can be used with the FFTF backup reactor design to assure that the system meets functional requirements and perfor'ms reliably. One design is a dual function (shim and scram) drive and the other is a scram drive only.
The control system for the FFTF backup design consists of a primary control system (with a ten inch offset beam) located in the reflector position, and a backup control system located in the incore position. By placing the primary control system on the periphery of the core and using movable reflectors with poison followers, sufficient space is available to use a larger number of low worth rods. 
The scope of this effort includes developing the two drives to meet the limited space requirements, building a prototype of both drives, and performance testing of each on mock-up test facilities which simulate reactor conditions except for radiation. Prior to completion of the design and testing of the prototypes, local areas of the design may be investigated experimentally such as the seal between the primary sodium coolant and the argon cover gas.

\subsection{PRIMARY REFLECTOR DRIVE}

The reference control rod drive system, including the scram cushion devices beneath the control blade and the offset beam are described in the Final Design Report GEAP-5722.

\subsection{IN-COKE SCRAM DRIVE}

No detail work on a different concept control rod drive was completed. The selection of the drive concept for the incore safety drives will be part of the development work.

\subsection{EVALUATION OBJECTIVES}

The intent of the evaluation program will be to assure that the design performs as required to meet high standards of reliability, low maintenance, safety, and life. Some of the areas which will be investigated are as follows:

- The drives will be tested to ascertain speed, friction, vibration, and wear.

- The leakảge in the seals and pistons will be measured.

- The control rod guide and bearing assemblies will be tested in an environmental test rig to determine wear characteristics and the effects of misalignment and tolerances on scram.

\subsubsection{Information Required}

- Determine operational characteristics

- Determine reliability characteristics

- Determine maintenance characteristics

- $\quad$ Analytically evaluate the impact of manufacturing tolerances and distortions on operation, reliability, and maintenance

- Evaluate wear, friction, vibration, speed characteristics of system

- Evaluate the seal design characteristics

- Evaluate effect of axial thermal gradient

- Evaluate effect of thermal transients.

- Analytically determine the effect of the forces developed during scram action for a stuck rod

- Evaluate effect of tolerances, bowing, crud buildup on the dash-pot cushion beneath the control blade.

- Evaluate suitability of the design of the springs beneath the offset beam as a means of absorbing excess scram potential and kinetic energy.

- Evaluater the effect of the stop-go operation for the primary (shim) drive. 


\section{SECTION V}

\section{VESSEL HEAD AND PLUGS}

\subsection{GUIDANCE AND CENTERING}

The Final Design Report GEAP-5722

describes the means by which the refueling and annular control plugs are removed, oriented, and replaced. A mockup rig to demonstrate the adequacy of the design to accomplish these procedures is required. The ability to compensate for probable malfunction - misalignment - tolerance phenomena should be demonstrated. Develop procedures for threading the open and closed loops through the head penetration.

\section{SECTION VI}

REFUELING AND REACTOR SERVICING SYSTEM

\subsection{INTRODUCTION}

The refueling and reactor servicing system is based upon an open reactor, hot cell concept similar to that used in the SEFOR facility. This system may be described as visual, remote-manual, since refueling operations may be performed remotely by operators viewing the fuel handling equipment and the upper region of the reactor. Servicing operations and component transfers which involve exposure of radioactive materials will be carried out remotely by visual conformation of events to as great a degree as practical. In addition, direct access to the refueling cell is provided for maintenance and servicing operations which do not involve exposure of radioactive materials. These operations would be performed when shielding is in place over the reactor vessel, fuel storage tanks, and primary coolant lines.

The "open reactor - hot cell" concept provides a great deal of versatility for efficiently performing the driver fuel handing, experiment liandling, and reactor servicing tasks. This is especially im- portant for a test reactor where test equipment, and thus handling requirements, may continually change and where a high plant factor is most desirable. Development effort is required, however, to enable utilization of the capabilities provided by this concept.

The primary objectives of the Refueling and Test Reactor Servicing System development program follow:

- Develop the "open reactor - hot cell" concept for FFTF fuel handling, experiment handling, and reactor servicing.

- Develop and lest prototypic cquipment and connectors to be utilized in the refucling cell.

- Establish and optimize methods for routinely performed remote handling operations.

- Experimentally determine heat loss capability of prototypic test and driver fuel transfer thimbles. 


\subsection{DEVELOPMENT PROGRAM}

The development program for the "Refueling and Reactor Servicing System" can be divided into two categories.

- Full size non-environmental mock-up.

- Environmental (sodium and inert gas) evaluation of refueling cell systems and equipment.

A full size mock-up is required to develop the cell configuration, equipment arrangement, and operational methods necessary for efficiently performing the many tasks anticipated. Many of the cell and reactor features can be mocked-up at minimal expense since size and location are the major requirements. Prototypic handling equipment and some prototypic reactor or test components, however, will be required to properly represent the actual operations. Some of the problems to be investigated are (1) offset indexed grappling and positioning, (2) instrumentation connect and disconnect, (3) closed loop pipe connect and disconnect, (4) experiment handling, and (5) servicing operations on components such as reactor vessel head and its attachments, in-vessel supports, and the hydraulic hold-down header. Since these are basically arrangement, handling, and manipulation tasks, actual environmental conditions (sodium and inert gas) are not required. The non-environmental type of facility not only minimizes the cost but enables easy access and modification while carrying out the test program.

An environmental test facility is required to evaluate and develop mechanisms that must operate in and out of sodium. Development tests must also be conducted on spent fuel transfer components (both driver fuel and test assemblies) to develop proper temperature and sodium vapor control. This facility would provide the representative equivalent fuel decay heat generation, inert gas, and sodium conditions but would not necessarily be the full size of the refueling cell. The height of the test cell and depth of the sodium filled vessel must be adequate to handle prototypic transfer component parts and therefore is somewhat similar to actual refueling cell and reactor vessel elevations. The cell, in plan view, need only be large enough to carry on the environmental tests and thus would be appreciably smaller than the actual cell. Other uses of this facility would include evaluation and development work on seals, closed loop coolant connections, reactor instrumentation connections, core clamping devices, inert gas temperature distribution near the top of the reactor, and devices for removing spilled sodium.

\subsubsection{Required Information}

- Develop practical, efficient and reliable "open reactor - hot cell" fuel handling, experiment handling, and reactor servicing operations.

- Evaluate prototype handling equipment and connectors operating under conditions to be encountered in hot cell operations.

- Establish criteria for monitoring sodium vapor deposition and means to contrul sudium evaporation during open pool visual refueling operations.

- Determine the heat loss capability and characteristics for driver fuel (and other hot sodium vapor components) transfer thimbles.

- Evaluate techniques for fuel and other core component cleaning. 
Evaluate and develop methods for diagnosis and repair of failures of components in and around the reac- tor vessel, using air-cell and inertgas operations as required.

\section{SECTION VII}

\section{SAFETY}

\subsection{DISCUSSION}

The general safety considerations of consequence are similar for both the reference and the backup designs. The details of a thorough safety evaluation and test program, however, will differ because of the design differences between concepts. An example of this difference would be in the design of the head to accommodate the Design Basis Accident. The backup design head and head penetrations are altogether different from those of the reference concept. The blast analysis and TNT test development program must be responsive to these fundamental differences.

Examples of safety areas common between both concepts follow:

- Subcriticality measurement during refueling

- Fuel damage limits criteria

\section{- Definition of DBA}

- DBA analysis and testing on small. scale models

- Implications of DBA on plant design

- Evaluation of effect of flow reduction on fuel failure and failure propagation

- Experimental evaluation of duct in an array to contain a pressure pulse

- Evaluation of potential for sodium superheat under typical conditions

- Relationship of instrumentation accuracy, response time and reliability to core behavior under partial flow reduction, local blockage, and overpower transients and accidents.

\section{$\underline{\text { DISTRIBUTION }}$}

Pacific Northwest Laboratory

FFTF Project

P. O. Box 220

Richland, Washington 99352

Attn: Supervisor of Configurations Contract 